\title{
DIFFERENT PROTOCOLS OF POSTCONDITIONING DOES NOT ATTENUATE MESENTERIC ISCHEMIA-REPERFUSION INJURY AFTER SHORT-TERM REPERFUSION
}

\author{
Diferentes protocolos de pós-condicionamento não atenua a lesão de isquemia e reperfusão mesentérica após curto período de reperfusão
}

Marcus Vinicius Henriques BRITO', Edson Yuzur YASOJIMA', Andressa Abnader MACHADO',

Matheus Paiva Pacheco Reis SILVEIRA', Renan Kleber Costa TEIXEIRA', Vitor Nagai YAMAKI', Felipe Lobato da Silva COSTA ${ }^{1}$

From the 'Laboratório de Cirurgia Experimental, Faculdade de Medicina, Universidade Estadual do Pará ('Laboratory of Experimental Surgery, Faculty of Medicine, State University of Pará - UEPA), Belém, PA, Brazil.

HEADINGS - Mesenteric vascular disease. Small intestine. Post-conditioning. Rats.
ABSTRACT - Background: Mesenteric ischemia is a challenging diagnosis. Delay in diagnosis can lead to extent bowel necrosis and poor outcomes. Ischemia and reperfusion syndrome plays an important role in this scenario. Aim: To access effects of different post-conditioning cycles on mesenteric ischemia-reperfusion syndrome. Method: Twenty-five rats were assigned into five groups: Sham, used to establish normal parameters; control group, submitted to mesenteric ischemia for 30 min; in groups GP3, GP1 and GP30, ischemia was followed by postconditioning protocol, which consisted of 1 cycle of $3 \mathrm{~min}$ (GP3), 3 cycles of $1 \mathrm{~min}$ (GP1) or 6 cycles of $30 \mathrm{~s}$ (GP30), respectively. lleum samples were harvested after one hour of reperfusion. Intestinal mucosal injury was evaluated through histopathological analysis. Results: The average of mesenteric injury degree was 0 in the sham group, 3.6 in the control group, 3.4 in GP3, 3.2 in GP1, and 3.0 in GP30; villous length average was 161.59 in sham group, 136.27 in control group, 135.89 in GP3, 129.46 in GP1, and 135.18 in GP30. Was found significant difference between sham and other groups $(p<0.05)$; however, there was no difference among post-conditioning groups. Conclusion: Post-conditioning adopted protocols were not able to protect intestinal mucosa integrity after mesenteric ischemia and short term reperfusion.

\section{Correspondência:}

Renan Kleber Costa Teixeira

E-mail: renankleberc@hotmail.com

Fonte de financiamento: não há

Conflito de interesse: não há.

Recebido para publicação:

Aceito para publicação:

DESCRITORES - Doença vascular intestinal. Intestino delgado. Pós-condicionamento. Ratos
RESUMO - Racional: O desfecho satisfatório na abordagem cirúrgica da obesidade deve contemplar, além da perda de peso, alteração significativa nas comorbidades preexistentes e na qualidade de vida dos pacientes. Objetivo: Avaliar a qualidade de vida no pós-operatório tardio de pacientes submetidos à cirurgia de gastrectomia vertical por videolaparoscopia. Métodos: Foi aplicado o questionário "Bariatric Analysis and Reporting Outcome System" (BAROS) em pacientes submetidos à gastrectomia vertical por videolaparoscopia. Resultados: Foram avaliados 47 pacientes, entre 21 e 60 anos de idade. O IMC médio antes da operação era $43,06 \pm 5,87 \mathrm{~kg} / \mathrm{m}^{2}$. A média percentual de redução do excesso de peso após foi de $85,46 \pm 23,6 \%$. A pontuação obtida pelos pacientes no questionário sobre a melhora na qualidade de vida evidenciou resultado excelente $(36,17 \%)$, ótimo $(40,43 \%)$, bom $(21,28 \%)$ e razoável $(2,13 \%)$. Houve melhora clínica após a operação em todas as comorbidades investigadas. Conclusão: A perda de peso foi fundamental para a melhoria na qualidade de vida e proporcionou resolução ou a melhora clínica em todas as comorbidades investigadas.

\section{INTRODUCTION}

(cc) BY This is an open-acces article distributed under the terms of the Creative Commons Attribution License.
$\mathrm{M}$ esenteric ischemia is a challenging diagnosis. Delay in doing it can lead to extent bowel necrosis and poor outcomes; carrying various consequences after surgery such as diarrhea, poor absorption, short bowel syndrome and death. Ischemia and reperfusion syndrome plays an important role in this scenario ${ }^{9}$.

During ischemia there is $\mathrm{Na}^{+} / \mathrm{K}^{+}$pump failure, $\mathrm{Ca}^{2+}$ influx, acidic substances formation, promoting endothelial injury, increasing permeability of the microcirculation and tissue edema that activates inflammatory response ${ }^{13}$. However, tissue damage is not limited to ischemia. When tissue oxygenation is restored, tissue damage is worsened by the reperfusion injury that is even more deleterious than ischemia ${ }^{2,10,11,24}$.

Aiming to minimize deleterious effects of ischemia and reperfusion injury, Murry et al. ${ }^{14}$ introduced the concept of ischemic preconditioning, which consists of short periods of ischemia followed by short reperfusion, before a longer ischemic phase, in order to induce organ tolerance to the ischemia-reperfusion injury ${ }^{14,19}$. Several clinical and experimental studies proved the protective effect of the ischemic preconditioning, as well as, its ability to reduce tissue damage ${ }^{7,15,17}$. However, in certain clinical settings, it is often difficult to foresee when ischemia will occur, limiting the preconditioning applicability ${ }^{19}$.

In 2003 Zhao et al. ${ }^{25}$ started the concept of ischemic post-conditioning, which consists in performing short cycles of ischemia followed by short cycles of reperfusion, 
immediately after the ischemia, and before the permanent reperfusion. Experimental studies have shown that ischemic post-conditioning is effective on preventing ischemia-reperfusion injury in several tissues, having a similar effect to ischemic preconditioning ${ }^{5,12,20}$. However, when analyzed in a hyper acute phase, post-conditioning was not able to reduce the damage caused by ischemia and reperfusion syndrome ${ }^{1}$.

Thus this study intends to investigate the effects of different post-conditioning cycles on induced-mesenteric ischemia-reperfusion injury in a short-term reperfusion period.

\section{METHODS}

This study was approved by the Ethics Committee for the Use of Animals of the State University of Pará - UEPA, protocol22/10. Twenty five male Wistar rats (Rattus norvegicus) obtained from the Animal Colony of the Experimental Surgery Laboratory of UEPA were used. They weighed 200-240 $\mathrm{g}$ and were kept in a controlled environment with food and water ad libitum. The animals were randomly assigned into five study groups $(n=5)$, according to the protocol (Figure 1): 1) sham group (SHAM), same surgical procedure as in remaining groups was performed, but no intestinal ischemia was induced; 2) control group (CG), intestinal ischemia was induced for 30 min followed by reperfusion without any form of conditioning; 3 ) post-conditioning group $3 \mathrm{~min}$ (GP3), intestinal ischemia was treated by 1 cycle of reperfusion interspersed by 1 cycle of ischemia, lasting 3 min each; 4) post-conditioning group $1 \mathrm{~min}$ (GP1), intestinal ischemia was treated by 3 cycles of reperfusion interspersed by 3 cycles of ischemia, lasting 1 min each; 5) post-conditioning group $30 \mathrm{~s}$ (GP30), intestinal ischemia was treated by 6 cycles of reperfusion interspersed by 6 cycles of ischemia, lasting $30 \mathrm{~s}$ each.

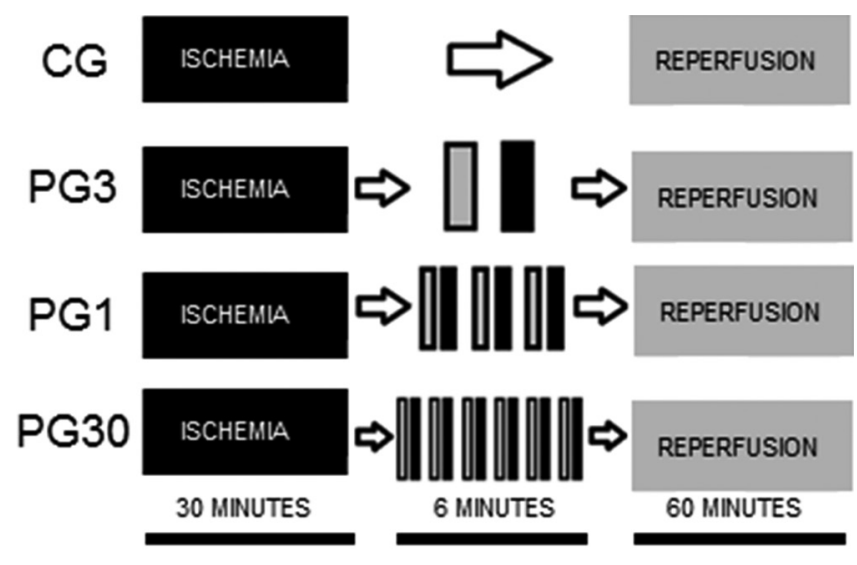

FIGURE 1-Diagram illustrating the post-conditioning protocols

All surgical procedures were performed under anesthesia (ketamine- $70 \mathrm{mg} / \mathrm{kg}$ and xylazine $-10 \mathrm{mg} / \mathrm{kg}$, intraperitoneally). Midline laparotomy was performed. During all procedure, the bowel was protected by gauze with heated saline. The mesenteric artery was identified and dissected, and it was occluded by a vascular clamp for $30 \mathrm{~min}$. After the artery was clamped, the small intestine was repositioned inside the abdominal cavity and the skin was closed with 5-0 nylon stitches.

After the ischemic cycle, the abdominal cavity was reopened through removal of the stitches. Vascular clamp was taken off, starting the reperfusion period, lasting $60 \mathrm{~min}$. In GP3, GP1 and GP30 groups, the ischemic post-conditioning were performed according the prior protocol described. After postconditioning protocol, abdomen was again closed with continuous 5-0 nylon stitches until the end of reperfusion period.

After reperfusion, the animals were euthanized by intravenous $\mathrm{KCl}$ injection. Immediately after, a $3 \mathrm{~cm}$ ileum sample distant $5 \mathrm{~cm}$ from the cecum valve was harvested. This fragment was fixed in $10 \%$ buffered formaldehyde, and underwent histological processing; the slides were stained with $H \& E$ and examined under light microscopy to determine the degree of injury based on the scale of Chiu et al. ${ }^{4}$ and villous length measurements were done by measuring ten well-oriented villous (cut across its length) in each of the animals.

\section{Statistical analysis}

ANOVA test was used to compare villous length; KruskalWallis test, to compare the histopathological results, and the Pearson's Linear Correlation test to determine whether there was a relationship between the score of intestinal injury and villous length. Significance level of $5 \%$ to reject the null hypothesis was adopted.

RESULTS

During the procedure no animal died or resuscitation maneuvers were performed. The mean score of intestinal injury is demonstrated on Table 1. Sham group showed a normal mucosa, and there was significant difference between this group to all others who underwent ischemia; among the other groups there was no significant difference $(p>0.05)$.

TABLE 1 - Mean and standard deviation of intestinal injury score according the groups

\begin{tabular}{|c|c|c|c|c|c|}
\hline Group & $\mathrm{SG}^{*}$ & CG & PG3 & PG1 & PG30 \\
\hline Score & $0.00 \pm 0.00$ & $3.60 \pm 0.57$ & $3.40 \pm 0.54$ & $3.20 \pm 0.44$ & $3.00 \pm 0.70$ \\
\hline
\end{tabular}

$\mathrm{p}<0.05$ SG vs. other groups (Kruskal-Wallis)

In relation to the villous length (Table 2), there was difference between the SHAM and the others groups $(p<0.05)$; however, there was no difference between the CG and the post-conditioning groups $(p>0.05)$. Relationship between score of intestinal injury and the villous length $(p=0.0004$ Pearson's $r=-0.6771)$.

TABLE 2 - Mean and standard deviation of villous length according the groups

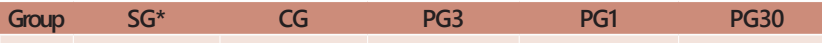 \\ \begin{tabular}{l|l|l|l|l|l} 
Score & $161.59 \pm 7.04$ & $136.27 \pm 8.80$ & $135.89 \pm 5.40$ & $129.46 \pm 16.04$ & $135.18 \pm 12.88$
\end{tabular}} $p<0.05$ SG vs. other groups (ANOVA)

\section{DISCUSSION}

After an ischemic event, reestablishment of blood inflow is the only approach to stop ischemic cascade ${ }^{2,22}$. However, reperfusion may end up with reactive oxygen species formation and increase in inflammatory reaction ${ }^{2,22}$.

To mitigate deleterious effects of ischemia and reperfusion the use of hypertonic solution $s^{23}$, herbals ${ }^{3}$ and oxygen therapy ${ }^{16}$ have been proposed. The currently most effective therapies are the ischemic conditioning techniques $5,7,18,21,22$. The postconditioning excels for its greatest clinical applicability compared to preconditioning, since in some clinical scenarios there is no way to predict when a tissue will be under ischemia ${ }^{5,20,25}$.

The post-conditioning works primarily by reducing reperfusion injury 5,20,22,25, Although, when analyzed after a short-term reperfusion period it shows a poor protection of structural tissue injury ${ }^{1}$. Therefore, this study intended to identify if different post-conditioning protocols could minimize early intestinal mucosa damage after ischemia-reperfusion syndrome.

Our data showed that all adopted post-conditioning protocols failed to minimize early intestinal mucosa damage secondary to ischemia and reperfusion syndrome. Such result does not invalidate or reduce the importance of ischemic post- 
conditioning ${ }^{1}$, yet, such fact reveals that there is no significant reperfusion structural damage after a short-term reperfusion period, possibly because there is a critical reperfusion time when it is possible to detect morphological damage.

This finding stands great importance, since during early reperfusion there is higher formation of oxygen radicals, but they are not capable to induce structural damage to the tissue ${ }^{6}$. On the other hand, it is possible that ischemia-reperfusion damage was mitigated by post-conditioning if cell biomarkers were analyzed, but there was not enough time of reperfusion to detect intestinal mucosa morphological damage on optical microscopy. Thus, further studies should be conducted measuring cell function markers and structure measurements to better understand postconditioning short term effects, as well if there is any difference among the adopted postconditioning protocols.

The number of adopted postconditioning cycles did not modify the outcome. There is no consensus in literature regarding the standard pattern of post-conditioning cycles to be performed in each organ since cell metabolism might influence the number of cycles and their duration, but it is known that short cycles are more effective than long cycles s, $, 12,20,25$

The negative result of this research does not indicate failure ${ }^{1}$. The acquisition of knowledge with possible errors, preventing other researchers to repeat the same method of study, justifies the publication of unfavorable results, a practice that should be estimulated ${ }^{8}$.

\section{CONCLUSION}

Adopted post-conditioning protocols had no effect on protecting intestinal mucosa morphology after mesenteric ischemia and short-term reperfusion injury.

\section{REFERENCES}

1. Bretz B, Blaze C, Parry N, Kudej RK. Ischemic postconditioning does not attenuate ischemia-reperfusion injury of rabbit small intestine. Vet Surg. 2010; 39(2): 216-23

2. Brito MVH, Araújo M, Acácio GJS, Acácio GJS, Reis JMC. Lesão intestinal após isquemia-reperfusão: estudo comparativo usando sal tetrazólico (MTT) e histologia. Acta Cir Bras. 2001; 16(1): 26-31.

3. Brito MVH, Moreira RJ, Tavares MLC, Carballo MCS, Carneiro TX, Santos AAS. Efeito do óleo de copaíba nos níveis séricos de uréia e creatinina em ratos submetidos à síndrome de isquemia e reperfusão renal. Acta Cir Bras. 2005; 20(3): 243-6.

4. Chiu CT, Scott HJ, Gurd FN. Intestinal mucosal lesion in low-flow states: II. The protective effect of intraluminal glucose as energy substrate. Arch Surg 1970; 101:484-8

5. Chu W, Li S, Wang S, Yan A, Nie L. Ischemic postconditioning provides protection against ischemia-reperfusion injury in intestines of rats. Int J Clin Exp Pathol. 2015 Jun 1;8(6):6474-81.

6. Francisco Neto A, Silva JCCB, Fagundes DJ, Percário S, Novo NF, Juliano Y, Moreira Neto AA. Estudo das alterações oxidativas, da capacidade antioxidante total e do óxido nítrico, em ratos submetidos à isquemia e reperfusão de membros posteriores. Acta Cir Bras. 2005; 20(2): 134-9.

7. Gao J, Zhao L, Wang Y, Teng Q, Liang L, Zhang J. Effect of limb ischemic preconditioning on myocardial apoptosis-related proteins in ischemiareperfusion injury. Exp Ther Med. 2013; 5(5): 1305-9.
8. Gomes HM, Serigiolle LC, Rodrigues DA, Lopes CM, Studart SV, Leme PL. Unfeasible experimental model of normothermic hepatic ischemia and reperfusion in rats using the Pringle maneuver. $A B C D$, Arq. Bras. Cir. Dig. 2014; 27(3): 196-200.

9. Higa OH, Parra ER, Ab'SaberAM, FarhatC, Higa R, Capelozzi VL.Protective effects of ascorbicacid pretreatment in a rat model of intestinal ischemiareperfusion injury: a histomorphometric study. Acta Cir Bras. 2007; 62(3): 315-20.

10. HortonJW, WalkerPB.Oxygen radicals, lipid peroxidation and permeability changes after intestinal ischemia and reperfusion. J Appl Physiol. 1993; 74(4):1515-20.

11. Kahlow BS, Nery RA, Skare TL, Ribas CA, Ramos GP, Petisco RD. ON VASCULARSTENOSIS, RESTENOSISANDMANNOSEBINDINGLECTIN.Arq BrasCirDig.2016Mar;29(1):57-9.doi:10.1590/0102-6720201600010015

12. LintzJA, DalioMB,JovilianoEE, PiccinatoCE. Ischemicpreand postconditioning in skeletal muscle injury produced by ischemia and reperfusion in rats. Acta Cir Bras. 2013; 28(6): 441-6.

13. Magalhães MA, Barbosa AJ, Figueiredo JA, Alberti LR, Petroianu A. Effects of different periods of gastric ischaemia in the viability of the tissue of body, fundus and antrum region of rabbit stomach. Arq Bras Cir Dig. 2015Jul-Sep:28(3):167-70.doi:10.1590/S0102-67202015nahead00001.

14. Murry CE, Jennings RB, Reimer KA. Preconditioning with ischemia: a delay of lethal cell injury in ischemic myocardium. Circulation. 1986; 74(5): 1124-36

15. Neves JS, Abrahão MS, Salzedas Netto AA, Montero EFS, Gonzalez AM. Effects of ischemic preconditioning associated to different preservation solutions in protecting the intestinal graft. Acta Cir Bras. 2011; 26(5): 396-403.

16. Paulo MSL, Paulo ICAL, Nunes TA, da Silva al, Cintra LC, Paulo DNS. Effect of hyperbaric oxygen therapy in rats with subtotal splenectomy preserving the inferior pole. Acta Cir Bras. 2011; 26(3): 156-64.

17. Saes GF, Zerati AE, Wolosker N, Ragazzo L, Rosoky RMA, Ritti-Dias RM, Cucato GG, Chehuen M, Farah BQ, Puech-Leão P. Remote ischemic preconditioning in patients with intermittent claudication. Clinics. 2013; 68(4): 495-9.

18. Santos CH, Aydos RD, Nogueira Neto E, Miiji LN, Cassino PC, Ahmed II, Calheiros NM, Garcia M, Silva AF. Importance of duration and number of ischemic postconditioning cycles in preventing reperfusion mesenteric injuries. Experimental study in rats. Acta Cir Bras. 2015; 30(10): 709-14.

19. SantosCHM,GomesOM,MiijiLNO, BispoMAF.Theischemicpreconditioning and postconditioning effect on the intestinal mucosa of rats undergoing mesentericischemia/reperfusion procedure.ActaCirBras.2008;23(1):22-8.

20. Santos CHM, Gomes OM, Pontes JCD Vieira, Miiji LNO, Bispo MAF. The ischemic preconditioning and postconditioning effect on the intestinal mucosa of rats undergoing mesenteric ischemia/reperfusion procedure. Acta Cir. Bras. 2008; 23(1): 22-8.

21. Yamaki IN, Pontes RVS, Costa FLS, Yamaki VN, Teixeira RKC, Yasojima $\mathrm{EY}$, Brito MVH. Kidney ischemia and reperfunsion syndrome: effect of lidocaineand local postconditioning. Rev.Col.Bras.Cir.2016;43(5):348-53.

22. Yamaki VN, Goncalves TB, Coelho JVB, Pontes RVS, Costa FLS, Brito $\mathrm{MVH}$. Efeito protetor do per-condicionamento isquêmico remoto nas lesões da síndrome de isquemia e reperfusão renal em ratos. Rev. Col. Bras. Cir. 2012; 39(6): 529-33.

23. Yamaki VN, Teixeira RKC, Brito MVH. Use of hypertonic solutions for liver preservation in rats. ABCD, Arq. Bras. Cir. Dig. 2013; 26(1): 44-8.

24. Zanchet MV, Silva LL, Matias JE, Coelho JC. POST-REPERFUSION LIVER BIOPSY AND ITS VALUE IN PREDICTING MORTALITY AND GRAFT DYSFUNCTION AFTER LIVER TRANSPLANTATION. Arq Bras Cir Dig. 2016 Jul-Sep;29(3):189-193. doi: 10.1590/0102-6720201600030014.

25. Zhao ZQ, Corvera JS, Halkos ME, Kerendi F, Wang NP, Guyton RA, VintenJohansen J. Inhibition of myocardial injury by ischemic postconditioning during reperfusion: comparison with ischemic preconditioning. Am. J. Physiol. Heart Circ. Physiol. 2003; 285(2): 579-88. 